NBER WORKING PAPER SERIES

THE EFFICIENT LEVEL OF PUBLIC LIBRARY SERVICES

Malcolm Getz

Working Paper No. $\underline{3} 2 \underline{1}$

NATIONAL BUREAU OF ECONOMIC RESEARCH

1050 Massachusetts Avenue

Cambridge MA 02138

February 1979

This study was supported by grants from the Book of the Month Club and the Scherman Foundation to the NBER. The author is solely responsible for the views expressed. 


\title{
ABSTRACT
}

\section{THE EFFICIENT LEVEL OF PUBLIC LIBRARY SERVICES}

\begin{abstract}
Criteria for determining the efficient mix of branches, hours, stock, and new acquisitions are developed and applied to the branch operations of the New York Public Library. A method based on travelling costs is used to value library use at each branch. The relationship between library operations and library use is estimated using a two-stage technique. The costs of library operations are explored. Marginal benefit-cost ratios are presented. The study finds that the New York Public Library operates too many branches for too few hours of service.
\end{abstract}

\author{
Malcolm Getz \\ Box 6221 B \\ Vanderbilt University \\ Nashville, Tennessee 37235 \\ (615) $322-2872$
}




\title{
THE EFFICIENT LEVEL OF PUBLIC LIBRARY SERVICES
}

\author{
Malcolm Getzl
}

In the era of fiscal austerity and Proposition 13 fever, the issue of determining the efficient level of local government services is particularly acute. Public libraries are more vulnerable to cutbacks than other services because library closings do not represent the immediate threat to public health or safety which fire, police, and sanitation cutbacks imply.

In fact, public library budgets are subject to wide swings. For example, the Buffalo-Erie County Public Library suffered a 27-percent cutback in budget in 1977; 11 percent was restored in 1978. Such erratic budget changes tend to destroy the morale of library employees, disrupt orderly management, and disturb public habits of library use. Because library use and public sentiment toward libraries are not subject to such severe short-term swings, it would seem that budget officers make changes with little evidence to guide them. They mav be experimenting to discover the effect of different budget levels.

Formal methods for evaluating the efficiency of different levels of operation might lead to greater budget stability by making specific requests for change more defensible. of course, formal methods involve aggregation, abstraction, and wrestling with difficult problems of valuation; and they do not replace informed judgment. However, a formal approach to budget evaluation can pinpoint the area 
in which judgment must be applied and thus heip avoid the destructive pattern of budget instability which characterizes many pubiic libraries.

Formal analysis can also provide insight into the efficient mixture of library expenditures. Perhaps more benefits can be derived per doliar of expenditure by changing the mixture. Rather than choosing between spending more and spending less, public library managers can use formal budget evaluation to spend more wisely.

In the discussion which follows, previous studies of library services are reviewed to establish the state of the art in evaluating libraries. The problem of determining the efficient number of branches is then discussed, using evidence from the branches of the New York Public Library. Efficient leveis of hours and book stock are addressed, again using data from the New York Public Library. Finaliy, a possible realiocation of expenditure with fewer branches operating ionger hours is evaluated.

\section{STUDYING EFFICIENCY IN LIBRARIES}

Efficiency is used here to mean deriving as much beriefit as possible from expenditures. Benefits are consumer valuations of services, and expenditures inciude the full social costs of activities. In competitive private markets, prices carry information about social costs and allow consumers to judge the level of service that makes them best off. Producers use revenues from sales as signais of how much to produce. However, when goods are provided collectiveiy, as with pubiic libraries, other means must be used to determine the efficient level of activity. 
The decision rule for a pattern of expenditure that will make consumers best off is simply stated: the additional benefit from one dollar of expenditure should be just one dollar. If the additional benefit were greater than one dollar, then the total benefit, net of costs, would increase with the additional expenditure, and the additional expenditure would be justified. If the additional benefit were less than one dollar, then reducing expenditures by one dollar would reduce costs more than benefits; thus benefits, net of costs, would be increased by cutting back. Of course, in order to operate the enterprise at all, total benefits must exceed total costs. But in most situations, the problem of choosing the most efficient level of operation--the level that makes consuniers best off--is the problem of identifying the level of service where the extra benefit of additional expenditure matches the cost.

The linkage between library expenditures and consumer benefits must be carefully defined and measured. First, how do expenditures generate services (the cost function)? Second, how much use is generated by the services (the production function)? Third, how do consumers value the different kinds of use (the valuation problem)? Other authors have considered the problem of evaluating library services. Their efforts are reviewed briefly here as background for the investigation to follow.

Several economists have applied benefit-cost analysis to library services. Newhouse and Alexander [13] focused on book selection in the Beverly Hills, California public library. They assumed that use of library materials represents some fraction of the value of ownership 
of the materials. Consequently, they suggested that the value of use of library materials is directly related to the purchase price of the materials (art books are more valuable than juvenile books, for example) and that value is directly related to the amount of use. By assuming that the same proportion of users would be likely to buy each type of book if the library copies are unavailable, Newhouse and Alexander estimated a valuation for each category of book and compared the values to the costs of the books. As a result of this analysis they recommended that the Beverly Hills Library buy more expensive and fewer inexpensive books.

The Newhouse and Alexander study is valuable because it deals directly with the problem of valuation, but the study has several limitations. Because they were uncertain how many users would buy books if the library copies were unavailable, the authors were unwilling to state the value of library use; they limited their conclusions to defining the best mixture of book purchases, given the book budget. Of course, the book budget is only one part of the design of a library. Newhouse and Alexander did not deal with the geographic character of public library services--namely, the number of branches--nor did they consider the issue of hours of service.

$\mathrm{Hu}$, Booms, and Kaltrieder [10] used benefit-cost methods to compare mail-order and bookmobile services in rural Pennsylvania. The average cost of the bookmobile service was $\$ 0.62$ per circulation, while the average cost of the mail-order service was $\$ 0.69$ per circulation. The mail-order service was more expensive because of the cost of preparing and mailing catalogs for selection. Estimated cost functions revealed 
that the operating cost per book circulated by the bookmobile service was $\$ 0.48$; the operating cost of the mail service was $\$ 0.60$.

The authors considered five different methods for establishing the benefits of the rural library services. First, they determined how much time was saved by users ordering books for delivery instead of making trips to the library. Second, they estimated the additional amount of money that users would have spent buying books if library service were less convenient. Third, the authors asked users what they would be willing to pay for the service. And fourth, they determined at what price books might be rented, if rentals were available. In addition, the authors considered the value of the option to use the service by people who do not use it, that is, the options demand for service. Because asking what users would pay is an unreliable method and because no rental services were in fact available in rural Pennsylvania, the analysts summed the time saved, the value of books not purchased, and the value of the options demand for service to establish the benefit for each service. They calculated the marginal benefit of rural delivery at $\$ .29$ for the bookmobile and $\$ .47$ for mail delivery. Thus, while mail delivery yields more benefits per dollar of expenditure than the bookmobile service, the benefits of neither system cover operating costs. The authors concluded that consumers in rural Pennsylvania are better off with the tax saving of visiting the library than with elaborate delivery systems. The Hu, Booms, and Kaltrieder study is noteworthy because it employs surveys of users and nonusers in developing estimates of benefits. Of course, 
the study of rural delivery is only tangentially relevant to the design of an urban system.

Other economists $[7,17]$ estimate cost functions of quasiproduction functions without trying to establish values for benefits, but they do not claim to identify efficient levels of service. In the best of these studies, Feldstein [6] estimated cost and circulation functions in 371 cities using a 1968 office of Education survey of public libraries. In estimating a use of relationship, Feldstein recognized that the library activities, branches, hours, and book stock might be shaped by library managers in light of patterns of use. Thus, the simple correlation between use and service level reflects both consumer behavior and managerial choice. While Feldstein used an instrumental variable technique to try to control for the simultaneity, it is not clear what variables were used as instruments. The use of city library systems as units of observation also caused some trouble because no distinction was made between a system with a large central library and small branches and one with a smaller central library and larger branches: Consequently, Feldstein could not develop statistical results to validate the claim that "fewer large branches is preferred to more small branches." Feldstein found that library use is sensitive to the level of service and that expenditures are shaped by local demographics and local government revenue services.

In an earlier study of library economics, Black [3] examined expenditure and use in a dynamic context. He recognized that library 
use would change with changes in population level, income, and wages. Assuming that the efficient level and mixture of services would be determined in response to use in this demographic context, Black emphasized the fact that efficient library service would change with time. Baumol and Marcus [1] considered the changing costs of academic library services, but did not provide an analytic framework. The fact that library costs are rising faster than other costs is not in itself a clue to determining efficiency. Operations research analysts have studied libraries in some detail. Although Hamburg, Clelland, Bommer, Ramist and Whitfield [8] have surveyed a substantial amount of this literature, they have contributed little to the problem of estimating the valuation that consumers place on library activities. They note that the average rate of return in the private sector is 12.5 percent. "By assuming that the average public library has benefits that exceed costs by 12.5 percent, we estimate the dollar value imputed to an exposure hour" [8, p. 33].

Operations research analysis appears to offer a better understanding of the production function than the more aggregate methods generally used by economists. In the best example of such work, Morse [2] analyzed the operation of the MIT library. He used queuing theory to determine the optimum number of multiple copies and a markov process to predict book use. Morse also considered the optimum length of loan period and the optimum number of reserves. These techniques are readily applicable in many library situations and deserve wide use. However, because Morse studied an academic library and emphasized operation issues, his 
approach offers little guidance in making budgetary choices for public library systems.

Raffel and Shishko [15] also used operations research in a study of the MIT library. The authors asked 283 students and faculty members to allocate a budget over 20 service changes. According to the responses, the authors distinguished two groups of users. The first (mainly students) preferred outside use: more duplicate copies for loan and longer loan periods. The other group (generally users engaged in research) favored increased acquisition, a messenger service with the Library of Congress, and department libraries. Using answers to hypothetical questions by relatively uninformed users may not be a reliable analytic technique. Nevertheless, the Raffel and Shishko study represents a creative effort to investigate the valuation of services in the context of an academic library, where the valuation problem is especially difficult.

Librarians, of course, have also been interested in evaluating library services. Lancaster's [11] comprehensive survey illustrates the strengths and the weaknesses of studies by librarians. Their main strengths are close attention to detail and sensitivity to nuances of service quality. For example, a study conducted by Crowley and Childers [4] assessed the quality of available reference services by asking a set of topical questions during anonymous telephone calls made at random times to public libraries in New Jersey. The authors found that the libraries generally did a poor job of responding to questions which required very current information (recent Presidential cabinet appointments, for example). It is easy 
to see how such surveys might be used by libraries to monitor their own telephone reference services and even to make judgments about the effectiveness of different training methods and work assignments. Another study by Seymour and Schofield [16] reported on the use of card catalogs. "Failures" were classified as follows: (1) item in catalog but not found; (2) item in library but not cataloged; (3) item on order; (4) identified item not in collection; and (5) unidentified citation. Clearly, an analysis of the first group of failures might lead to revision of catalog headings (if inexpensive); failures in the fourth category might give a clue to collections development. These detailed performance studies reflect the Iibrarian's concern with the quality of individual library activities.

Another attempt by librarians to develop performance indicators casts a broader net. DeProspo, Altman, and Beasley [5], under the auspices of the Public Library Association, propose a more comprehensive data-gathering effort using sampling techniques to describe the user success rate in finding materials (the probability of finding particular items from standard bibliographies in the catalog and on the shelves). A study of the scope proposed by the authors would include consideration of facilities use, reference, outreach, circulation, materials available, users, and in-library activity. The specific purpose of the proposed methods is to develop a broad base of information useful to library management, and, clearly, the use of sampling techniques represents a substantial improvement over current practice. 
The main deficiency of most evaluations by librarians is the lack of concern with costs. Lancaster gives little information about bench marks for the costs of different kinds of library activity, nor does he suggest how costs might usefully be measured. Even the comprehensive approach proposed by DeProspo, et al. is aimed at improving performance measures and gives short shrift to costs. Efficiency, however, cannot be defined without reference to costs.

The lack of concern with costs leads librarians into several traps. First, they like to talk about the number of people unserved by libraries: Usually, this seems to mean the residents of jurisdictions which have not chosen to build public libraries. But DeProspo, et al. broaden the reference: "Iowa and Minnesota show the percentage of population unserved by libraries, although it is not clear if the figures relate to the lack of a library in a given area or, more important, that a percentage of the population does not avail itself of library service" [5, p. 23]. The implication seems to be that, whatever the cost and whatever consumers' preferences, more should be spent on libraries until everyone uses them. Lancạster, only slightly more conservatively, cites the view that libraries should strive to satisfy 90 percent of the population's needs [11, p. 166]. The notion that the benefits of library services must be balanced against their costs is not reflected in the concept of an unserved population. Moreoever, this concept rejects consumer preference as a criterion for judging service levels.

A second trap created by the lack of concern with costs is the application of standards. The Public Library Association 
promulgated standards for public libraries in 1966 [14], specifying space, book stock, staffing, training, and so on. The description of a successful public library may be helpful. But the standards seem to suggest that communities which do not choose to buy elaborate library services are not acting responsibly. That some communities have difficulty raising taxes and do not value library services highly while others want to pay for high levels of service is easily understandable when efficiency is recognized to account for both benefits and costs and consumer preferences are used as the criteria for judging service. As costs, productivity, and tastes change, the level and mixture of library services different communities desire also change. The efficient set of public library activities has changed since 1966 and will continue to change. Since standards are fixed and unresponsive to change, they are not very helpful in evaluating the efficiency of library services.

Finally, a study of efficiency--that is, how benefits relate to costs--should focus on the cost of major library activities. For example, perhaps the most fundamental cost consideration in an urban public library system is how many branches of what size to operate; the second most important issue is how many hours to operate; the third is how many new books to add each year; and the fourth is the size of the central library. These are the major decisions that determine the size of a public library budget and to a substantial degree, the quality of service. Therefore, these items should be the principal target of evaluation. If the Lancaster survey is any indication, librarians appear to prefer to evaluate 
catalog use, reference service, information retrieval, and book collection. Lancaster's discussion of the evaluation of library services hardly mentions the number of branches, hours of service, or numbers of books, except to say that more is better.

In the analysis described below, cross-sectional evidence from the branch libraries of the New York Public Library is used to determine the efficient number of branches, books, and hours of service. Analysis of the efficient size of the central library services requires a different methodology because the central facilities in library systems are unique within each system. The present exercise is limited to a cross-sectional study focusing on neighborhood branches. The New York Public Library has been chosen for evaluation because its large number of branches facilitates a statistical anaiysis.

HOW MANY BRANCHES?

The first priority in judging the efficiency of an urban library system is determining the efficient number of branches. The evaluation paradigm is straightforward: the benefits and costs of each branch are measured and compared. Each branch is considered in turn as the marginal branch. The actual use of each branch is valued from the consumer's point of view. Because the estimates of costs and benefits are approximations, choices are made so as to give low estimates of costs and high estimates of benefits within the range of plausible values. 
The New York Public Library, a private, nonprofit, research library, operates branch libraries under contract from the City of New York in three boroughs: Manhattan, the Bronx, and Staten Island (Richmond County). Because the facilities of the research libraries are generally used on premise, their services are not close substitutes for the traditional public library services of the branches, and so they are ignored here. The branch libraries include a facility for the handicapped that provides services throughout the City and beyond. The service to handicapped persons is also not a close substitute for the traditional library services, so it too is excluded from the analysis.

The branches are classified as centers, regional libraries, and neighborhood libraries. The centers are the largest facllities; there is one in each borough, plus one for the whole system. The centers have an average book stock of over 120,000 volumes. The 13 regional libraries have an average stock of 33,000 volumes. There are 59 neighborhood libraries in the system; each has a permanent book stock, an average of 24,000 volumes, and staff. Two former neighborhood libraries which are operated at a marginal level without a permanent book stock or staff are not included in this analys is. In all, the branch libraries operate 76 regular, genera purpose facilities with permanent book stocks and staff. They serve an area of 122 square miles which in 1970 had a population of 3.3 million. Summary information for an average branch of each type and totals for all 76 facilities are reported in Table 3 . The three types of branches seem to differ in terms other than the size of the 
TABLE ?

Branches of the New York Public Library

\begin{tabular}{|c|c|c|c|c|}
\hline \multirow[t]{2}{*}{ I tem } & \multicolumn{3}{|c|}{ Average for Type } & \multirow{2}{*}{$\begin{array}{l}\text { Total } \\
\text { for } \\
\text { System }\end{array}$} \\
\hline & Neighborhood & Regional & Center & \\
\hline $\begin{array}{l}\text { Stock } \\
\text { Additions } \\
\text { Professional Staff } \\
\text { Other Staff } \\
\text { Hours of Service } \\
\text { (annual) } \\
\text { Square Feet } \\
\text { Adult Circulation } \\
\text { Juvenile Circulation } \\
\text { Adult Reference } \\
\text { Juvenile Reference } \\
\text { Total Usea } \\
\text { Costb }\end{array}$ & $\begin{array}{c}23,947 \\
2,685 \\
2.18 \\
3.89 \\
7,002 \\
9,442 \\
54,357 \\
22,470 \\
14,222 \\
7,749 \\
112,856 \\
\$ 200,108\end{array}$ & $\begin{array}{r}33,535 \\
3,743 \\
3.42 \\
5.46 \\
1,389 \\
16,335 \\
84,724 \\
33,073 \\
24,316 \\
9,969 \\
173,638 \\
\$ 337,920\end{array}$ & $\begin{array}{c}127,766 \\
219,288 \\
2 \quad 20.50 \\
6 \quad 23.88 \\
\\
2,733 \\
50,698 \\
456,364 \\
44,079 \\
425,123 \\
29,017 \\
1,046,163 \\
\$ 2,041,436\end{array}$ & $\begin{array}{r}2,333,282 \\
284,273 \\
255 \\
396 \\
\\
88,082 \\
972,257 \\
6,733,933 \\
1,937,960 \\
2,855,697 \\
702,840 \\
13,100,480 \\
\$ 24,365,708\end{array}$ \\
\hline $\begin{array}{l}\text { Use/Stock } \\
\text { Circulation/Stock } \\
\text { Cost/Use } \\
\text { Percent of Circulation-- }\end{array}$ & $\begin{array}{l}4.55 \\
3.21 \\
2.45\end{array}$ & $\begin{array}{l}5.10 \\
3.51 \\
2.59\end{array}$ & $\begin{array}{l}10.255 \\
4.13 \\
1.72\end{array}$ & $\begin{array}{l}4.94 \\
3.46 \\
2.43\end{array}$ \\
\hline $\begin{array}{l}\text { juvenile } \\
\text { Percent of Stock--added } \\
\text { Percent of Staff-- }\end{array}$ & $\begin{array}{l}29 \\
11\end{array}$ & $\begin{array}{l}28 \\
11\end{array}$ & $\begin{array}{l}09 \\
16\end{array}$ & $\begin{array}{l}24 \\
12\end{array}$ \\
\hline $\begin{array}{l}\text { professional } \\
\text { Number of Locations }\end{array}$ & $\begin{array}{l}34 \\
59\end{array}$ & $\begin{array}{l}39 \\
13\end{array}$ & $\begin{array}{r}44 \\
4\end{array}$ & $\begin{array}{l}39 \\
76\end{array}$ \\
\hline
\end{tabular}

Source: The New York Public Library, 1976-77 flows, 1977 stocks.

aTotal Use is reference questions plus 1.183 times circulation. The 1.183 factor is to account for in-library use. It is an average figure from a survey of library users in a sample of 15 neighborhood branches in the New York Public Library.

$\mathrm{b}^{\mathrm{b}}$ ost is based on the operating budget for each library. Reported budget figures anticipated for 1976-77 are adjusted for part-time staff shifts among branches as reported in library budget documents. In addition, 


\section{TABLE 1--continued}

Comprehensive Employment and Training Act Employees are added in at $\$ 9,000$ each. Operating costs are inflated by 20 percent to reflect the administrative overhead costs of the system. Rent payments actually paid are excluded from costs, but $\$ 5$ per square foot are included for each facility reflecting an approximation to the annual lease value of space. Actual rentals varied from under $\$ 3$ to over $\$ 9$ per square foot for the small number of facilities actually rented. 
book stock. The centers have larger staffs and operate more hours than the regional libraries, and the regionals operate with larger staffs and are open more hours than the neighborhood facilities. They also differ in respect to the proportion of professional staff, with the larger units having more professional staff than the smaller ones. Note, however, that the regional branches are much more like neighborhood branches than like centers.

The patterns of use of the three types of branches also differ. The amount of use per volume in stock is much larger for the library centers than for the regional libraries and somewhat larger for the regional than for the neighborhood libraries, whether use is defined simply as circulation or as the sum of reference questions and weighted for in-library use circulation. Consequently, the cost per use is lowest at the centers, and is somewhat lower at the neighborhood than at the regional facilities. The greater intensity of use probably reflects the fact that the larger facilities operate longer hours, have larger and more varied collections, add more books to their stocks, and have a more professional staff. On the other hand, the neighborhood libraries circulate a larger share of juvenile materials than the library centers. Surprisingly, however, juvenile materials are about as important at regional libraries as at neighborhood locations. The proximity of the neighborhood branches does not seem to dominate the regional facilities for juvenile use. Note that with 76 locations serving 122 square miles, the average branch serves 1.6 square miles. A circle with a radius of .71 miles subtends such an area. 


\section{Cost of Branches}

The first step in defining efficiency is an analysis of costs. The budgeted costs of the New York Public Library branch library system for 1976-77 are used here. The operating costs for each facility include staff costs with fringe benefits and supplies; the budget for the acquisition of new materials inflated by 34 percent to account for system processing costs; and plant security and maintenance costs. The operating costs are modified in several ways to reflect actual social costs. First, the staff work part-time in other branches. An approximate net value for such reassignments is used to adjust the budget figures. Also, Comprehensive Employment and Training Act supported employees are added in at $\$ 9,000$ each. Second, operating costs for each facility do not include the administrative overhead costs for borough and system offices: 20 percent is added to approximate such costs. Third, the budget includes rent expenditure for 15 facilities that are rented. In order to make the cost figures used in this study reflect the full social opportunity cost of the system, an annual lease value is assumed for each facility. Therefore a $\$ 5$ per square foot lease charge is included in the total costs. For this reason, the social cost figures used here exceed the budget for the library system by about $\$ 4$ million. The cost figures used here then are an attempt to estimate the full social costs of each facility including the local budget, federal support, and the value of facilities owned by the Library.

The costs of each facility can be related to the level of operation. The operations are summarized in three variables: annual 
hours of service, the total stock of materials both book and non-book, and the number of gross additions of stock during the year. The possibility that high levels of use raise costs given hours and books is ignored. The analysis reported in Table 2 indicates the marginal cost of an additional hour of service annually is approximately $\$ 2,317$, that is $\$ 44.56$ for a single hour. ${ }^{2}$ Maintaining an additional item in stock for a year is estimated to cost $\$ 3.93$. $^{3}$ The acquisition of a new item has an estimated marginal cost of $\$ 7.31$ including average processing costs. ${ }^{4}$ While over half of the variation in costs across neighborhood branches is accounted for by the three operations variables, it is a little disappointing that more of the cost differences are not explained. This weakness may be due in part to the fact that the budget and actual operations may not be for exactly the same time period, and expenditures may be somewhat different than budgets.

\section{Benefits of Branches}

The second step in the evaluation of branch activities is the evaluation of the use of the libraries. Library use is recorded in more detail by the New York Public Library than by many libraries. The circulation of books and other materials outside each branch is recorded separately for adult and juvenile materials. In addition the Library makes an effort to count the reference questions asked during several sample periods each year. Thus, the total number of reference questions asked can be estimated. The only major category of use that the Library does not routinely monitor is attendance; 
TABLE 2

A Regression Analysis of Costs

59 Neighborhood Branches of the New York Public Library

\begin{tabular}{lc}
\hline \multicolumn{1}{c}{ Item } & Coefficient \\
\hline Constant & $41,427.2^{\star \star}$ \\
& $(1.763)$ \\
Hours & $2,317.12^{\star}$ \\
& $(1.639)$ \\
Stock & $3.932^{\star \star \star}$ \\
& $(4.300)$ \\
Additions & $7.414 * \star \star$ \\
R-squared & $(2.801)$ \\
F(3,55) & .529 \\
\end{tabular}

Ordinary Least Squares Regression. The dependent variable is

budgeted costs for 1976-77 adjusted for staff reassignments and Comprehensive Employment and Training Act Employees. The operating costs excluding rents of each branch are inflated by 20 percent to account for system administration. $\$ 5$ per square foot of space is added to account the social opportunity cost of the space. Numbers in parentheses are t-statistics. Statistical significance is indicated as follows: *.10 lever; *夫.05 level;

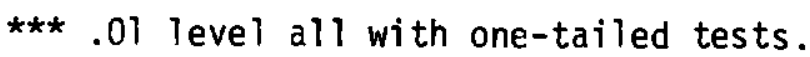


thus, the in-library use of materials is not systematicaliy known. The Library has undertaken a sample survey of users of 27 facilities in the system. Amiong users at 15 neighborhood branches, 15.5 percent indicate they planned to use materials in the library. Defining total materials use as circulation times 1.183 unts 15.5 vercent of moterials use in the library and 84.5 percent cutside the library. The in-library use for the salliple libraries val ited substantial1y from .05 to .31 of circulation, so sample figures on, attendance at every branch would improve the measurelitint ot library use. Totai use for this study is the sum of retererice gliestions Dius . IE3 times observed circulation.

The critical problem in making a judginent obut effictency is the valuation of use. We want to know what ibiriery ust is wirth to corisumers. The prices of goods and services gurchaser in chrinary markets carry important information about the valuction rotisumers nace on their purchases. If markets work approwriate ty tiat prices

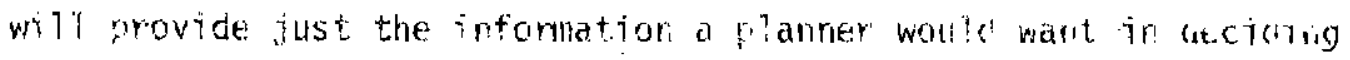
Just how much of a service to supply. Wher: charges arc not made for c merticular service, alternative nethods mas $t$ u usid id decide what value consumers gace on the services they consulute, :me way to estadish such a value for library service is th icitutufy bit whomer": next best a ternative and deternine ils cust to the

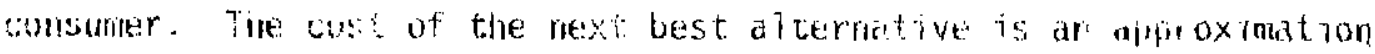
a the "alue of thr service actur ly useo.

The mext best aiterndive to an irividual branch library 's the next nearest branch library. If a single brimch were closed. 
current users would either discontinue library use (perhaps buyino more books or doing less reading) or visit the next most convenient branch library. For the user who would visit another library, the value of having a library nearby is simply the differential in travel time and cost of visiting a more distant library over visiting one nearby. As a rough average, the additional travel time and cost will be about the same as the cost of travel from the nearest litrary to the next nearest. For the user who would stop using the library if the nearest branch were to close, the value of library service must be less than the cost of visiting the next nearest library. At a maximum, the value of the nearest library branch is the cost in timle and money of travelling to the next nearest facility. Whether library use continues at another facility or ceases, the cost of travel to tile next nearest facility is an upper bound estimate of the value of its. services.

The method of valuing library use by looking at the cost of the next best alternative defines a value for an individual branch considered by itself. It does not reveal the vaiue of the full library system. If a single branch closes, some users will be diverted to other branches, and so the use of other facilities will change. In addition, the next nearest branch for some facilities may change when one facility is closed. Thus the proposed method for valuirin the library services is appropriate for valuing branches individually. The value of use of a particular branch is then assumed to be the cost of travelling between that location and the next nearest 
facility. Two uses are assumed to occur on each round trip. To calculate the travel time, straight-line distances are measured, and travel is assumed to take place at five miles per hour. Travel time is assumed to be valued at $\$ 4$ per hour. This implies a valuation of each library use of $\$ 0.80$ for each mile from a particular branch to the next nearest branch. In addition, $\$ 0.50$ additional transit fare is assumed each way of the round trip to the next nearest branch. For regional branches, the distance to the library centers is used. For the three borough centers, the Mid-Manhattan Library Center is taken as the alternative. No effort is made to value the services of the MidManhattan Center.

According to this method of valuation, branches with greater use and those located at a greater distance from regional libraries provide more benefits than the branches that are used less and those located near to other branches.

The valuation technique obviously does not give any clue as to the relative value of juvenile versus adult circulation, or of circulation versus reference versus in-library use. In order to account for the possibility that different uses will be valued differently, a second benefit calculation is made. Adult circulation is treated as before, whereas juvenile circulation is assumed to be worth 50 percent more than adult in light of the greater difficulty juveniles may have in travelling to another library. Reference questions are valued at half an adult circulation rate because many questions can be answered by telephone. In-library use is treated like circulation just as before. 
The estimated benefits and costs of the branches of the New York Public Library are reported in Table 3. Of the 59 neighborhood branches, 12 are estimated to have benefits greater than costs while 47 have benefits less than costs. Of the 12 with positive net benefits, 6 are in Staten Island, 5 are in the Bronx, and only one is in Manhattan. Of the 47 neighborhood branches with negative net benefits, 26 have benefits that are $\$ 100,000$ less than costs. Of these 26 branches, 22 are within one mile of the next nearest branch, including 7 that are within a half mile of the next nearest branch. Thus the close proximity of branches seems to be important in explaining the low level of benefits of many branches. A second factor, of course, is low levels of use.

Among the 13 regional libraries, 5 show negative net benefits according to these estimates. Of these 5, the Francis $X$. Martin Regional Library and the Grand Concourse Regional Library show benefits less than costs of more than $\$ 100,000$. Martin and Grand Concourse are about a mile apart and the Martin Regional is within a mile of the Fordham Library Center. These facts may explain the low level of benefits indicated for these regional branches.

The Fordham and St. Georges Library Centers show benefits substantially greater than costs. The valuation method does not allow an estimate of the benefit of the MidManhattan Library, the largest library in the branch system. The Donnell Library Center shows negative net benefits in part because it is within a mile of the MidManhattan. The Donnell Library Center may have specialized collections for Young Adults, however, and so the MidManhattan may 
TABLE 3

Costs and Benefits of Libraries

\begin{tabular}{|c|c|c|c|c|c|}
\hline $\begin{array}{l}\text { Neighborhood } \\
\text { Libraries }\end{array}$ & Use & Benefits & Costs & $\begin{array}{l}\text { Benefits- } \\
\text { Costs }\end{array}$ & $\begin{array}{l}\text { Weighted } \\
\text { Benefits- } \\
\text { Costs }\end{array}$ \\
\hline 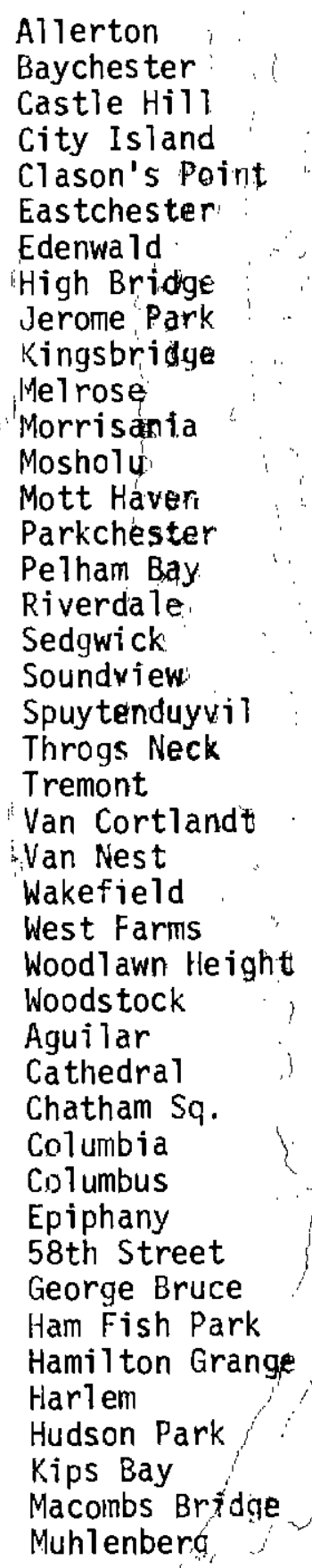 & $\begin{array}{r}149,213 \\
320,393 \\
49,140 \\
35,865 \\
105,979 \\
74,739 \\
112,016 \\
78,991 \\
81,070 \\
154,784 \\
66,452 \\
56,223 \\
184,716 \\
58,022 \\
204,027 \\
189,608 \\
124,375 \\
33,838 \\
102,355 \\
162,451 \\
171,748 \\
34,213 \\
80,717 \\
146,242 \\
94,744 \\
40,603 \\
58,995 \\
33,950 \\
65,278 \\
87,942 \\
260,821 \\
73,503 \\
42,130 \\
263,446 \\
201,013 \\
59,1521 \\
68,141 \\
101,474 \\
27,598 \\
60,161 \\
175,492 \\
18,514 \\
119,197\end{array}$ & $\begin{array}{r}172,974 \\
444,526 \\
57,277 \\
95,229 \\
133,603 \\
89,483 \\
183,249 \\
84,559 \\
81,646 \\
148,035 \\
87,986 \\
74,442 \\
245,041 \\
86,019 \\
224,919 \\
275,159 \\
199,684 \\
32,999 \\
120,210 \\
155,368 \\
204,912 \\
36,622 \\
98,482 \\
175,463 \\
115,597 \\
53,761 \\
71,980 \\
29,876 \\
70,500 \\
68,159 \\
203,441 \\
69,092 \\
50,556 \\
222,348 \\
160,810 \\
64,283 \\
61,327 \\
101,474 \\
23,403 \\
51,016 \\
143,903 \\
16,293 \\
125,395\end{array}$ & $\begin{array}{r}284,216 \\
361,976 \\
169,584 \\
79,164 \\
252,800 \\
127,316 \\
196,890 \\
199,228 \\
181,914 \\
286,039 \\
199,903 \\
231,827 \\
231,476 \\
264,710 \\
215,810 \\
220,646 \\
243,474 \\
86,198 \\
213,086 \\
217,758 \\
214,446 \\
174,123 \\
119,283 \\
206,396 \\
264,969 \\
240,609 \\
104,186 \\
244,044 \\
225,230 \\
112,950 \\
275,499 \\
80,618 \\
163,982 \\
282,484 \\
211,180 \\
240,382 \\
200,422 \\
243,243 \\
151,338 \\
194,551 \\
229,370 \\
35,579 \\
204,631\end{array}$ & $\begin{array}{r}-111,242 \\
82,550 \\
-112,307 \\
16,066 \\
-119,197 \\
-37,833 \\
-13,641 \\
-114,668 \\
-100,268 \\
-138,004 \\
-111,917 \\
-157,384 \\
13,565 \\
-178,691 \\
9,109 \\
54,513 \\
-43,790 \\
-53,199 \\
-92,876 \\
-62,390 \\
-9,534 \\
-137,501 \\
-20,801 \\
-30,933 \\
-149,372 \\
-186,848 \\
-32,206 \\
-214,168 \\
-154,730 \\
-44,791 \\
-72,058 \\
-11,525 \\
-113,426 \\
-60,136 \\
-50,370 \\
-176,099 \\
-139,095 \\
-141,768 \\
-127,935 \\
-143,534 \\
-85,467 \\
-19,286 \\
-79,236 \\
-136 \\
-190\end{array}$ & $\begin{array}{r}-117,008 \\
89,938 \\
-105,454 \\
19,218 \\
-107,885 \\
-37,842 \\
-3,138 \\
-105,291 \\
-90,487 \\
-133,877 \\
-98,110 \\
-151,526 \\
12,814 \\
-171,683 \\
17,216 \\
29,988 \\
-41,521 \\
-46,494 \\
-90,997 \\
-55,963 \\
15,674 \\
-132,230 \\
-18,776 \\
-27,793 \\
-154,721 \\
-189,956 \\
-29,996 \\
-213,702 \\
-149,257 \\
-49,648 \\
-46,496 \\
-15,444 \\
-114,233 \\
-61,833 \\
-60,863 \\
-172,076 \\
-137,866 \\
-137,171 \\
-128,995 \\
-140,659 \\
-84,808 \\
-17,163 \\
-87,120\end{array}$ \\
\hline
\end{tabular}


TABLE 3--continued

\begin{tabular}{|c|c|c|c|c|c|}
\hline $\begin{array}{l}\text { Neighborhood } \\
\text { Libraries }\end{array}$ & Use & Benefits & Costs & $\begin{array}{l}\text { Benefits- } \\
\text { Costs }\end{array}$ & $\begin{array}{l}\text { Weighted } \\
\text { Benefits- } \\
\text { Costs }\end{array}$ \\
\hline $\begin{array}{l}\text { 115th Street } \\
\text { 125th Street } \\
\text { 0ttendorfer } \\
\text { Riverside } \\
\text { Seward Park } \\
\text { 67th Street } \\
\text { Washington Heigh } \\
\text { Webster } \\
\text { Yorkville } \\
\text { Dongan Hills } \\
\text { Great Killis } \\
\text { Port Richmond } \\
\text { Stapleton } \\
\text { Todt Hill } \\
\text { Tottenville } \\
\text { West New Brighto }\end{array}$ & $\begin{array}{r}26,836 \\
27,511 \\
91,007 \\
322,040 \\
167,016 \\
102,051 \\
\text { ht } 59,419 \\
68,236 \\
334,593 \\
142,321 \\
230,284 \\
127,721 \\
64,964 \\
153,014 \\
47,455 \\
124,362\end{array}$ & $\begin{array}{r}24,689 \\
23,439 \\
75,062 \\
305,938 \\
130,272 \\
97,969 \\
52,289 \\
58,683 \\
287,750 \\
319,704 \\
785,416 \\
205,123 \\
108,116 \\
349,068 \\
348,321 \\
199,725\end{array}$ & $\begin{array}{r}170,450 \\
209,441 \\
176,954 \\
262,354 \\
337,560 \\
211,648 \\
204,761 \\
127,117 \\
314,101 \\
187,044 \\
214,049 \\
192,477 \\
126,786 \\
152,388 \\
89,545 \\
146,193\end{array}$ & $\begin{array}{r}-145,761 \\
-186,001 \\
-101,891 \\
43,584 \\
-207,288 \\
-113,679 \\
-152,472 \\
-68,434 \\
-26,351 \\
132,660 \\
571,367 \\
12,646 \\
-18,670 \\
196,680 \\
258,776 \\
53,532\end{array}$ & $\begin{array}{r}-143,394 \\
-186,611 \\
-103,650 \\
24,584 \\
-201,171 \\
-115,784 \\
-148,119 \\
-68,568 \\
-34,039 \\
152,803 \\
618,979 \\
8,980 \\
-14,898 \\
241,868 \\
291,905 \\
50,612\end{array}$ \\
\hline \multicolumn{6}{|c|}{ Regional Libraries } \\
\hline $\begin{array}{l}\text { Bloomingdale } \\
\text { Countee Cullen } \\
\text { Ft. Washington } \\
\text { Inwood } \\
\text { Jefferson Market } \\
96 \text { th Street } \\
\text { St. Agnes } \\
\text { Tompkins Sq. } \\
\text { Francis Martin } \\
\text { Grand Concourse } \\
\text { Hunts Point } \\
\text { Westchester Sq. } \\
\text { New Dorp }\end{array}$ & $\begin{array}{r}342,940 \\
64,893 \\
142,199 \\
233,386 \\
\mathrm{t} \\
368,156 \\
132,648 \\
153,770 \\
70,189 \\
116,793 \\
87,464 \\
101,933 \\
92,100 \\
350,735\end{array}$ & $\begin{array}{r}857,349 \\
246,937 \\
810,533 \\
1,563,684 \\
662,680 \\
298,511 \\
276,785 \\
133,358 \\
147,253 \\
160,165 \\
319,091 \\
282,489 \\
2,319,062\end{array}$ & $\begin{array}{l}408,709 \\
411,437 \\
325,543 \\
336,096 \\
515,837 \\
286,223 \\
302,374 \\
233,121 \\
363,278 \\
326,584 \\
285,383 \\
280,086 \\
318,288\end{array}$ & $\begin{array}{r}448,640 \\
-164,500 \\
484,990 \\
1,227,588 \\
146,843 \\
12,288 \\
-25,588 \\
-99,763 \\
-216,025 \\
-166,419 \\
33,708 \\
2,403 \\
2,000,774\end{array}$ & $\begin{array}{r}428,426 \\
-187,589 \\
460,702 \\
1,229,419 \\
122,489 \\
25,631 \\
-26,244 \\
-78,121 \\
-200,464 \\
-152,629 \\
42,787 \\
6,338 \\
2,147,089\end{array}$ \\
\hline \multicolumn{6}{|l|}{ Library Centers } \\
\hline $\begin{array}{l}\text { Donnel } \\
\text { Mid Manhattan } \\
\text { Fordham } \\
\text { St. Georges }\end{array}$ & $\begin{array}{r}1,431,242 \\
1,938,887 \\
460,163 \\
354,359\end{array}$ & $\begin{array}{c}1,395,747 \\
\text { (a) } \\
3,543,255 \\
2,809,644\end{array}$ & $\begin{array}{c}2,360,029 \\
(a) \\
678,892 \\
478,950\end{array}$ & $\begin{array}{c}-964,282 \\
(a) \\
2,864,363 \\
2,330,694\end{array}$ & $\begin{array}{c}-1,176,669 \\
(a) \\
2,480,005 \\
1,874,776\end{array}$ \\
\hline
\end{tabular}

Note: Use is the sum of reference questions plus 1.183 times circulation. Benefits and costs are in dollars, and are defined in the text.

(a) not applicable. 
not be a close substitute. The valuation method is on a firmer footing in evaluating the neighborhood and regional facilities. When use of juvenile materials is weighted 50 percent more than the use of adult materials, and reference questions are weighted at half the value of use of adult materials, the net benefit picture changes little. Only the Throgs Neck Branch moves from negative net benefits to positive net benefits. The number of branches with net benefits less than minus $\$ 100,000$ drops from 26 to 24 .

The estimates of benefits and costs presented here indicate that the New York Public Library operates many more branches than is dictated by efficiency criteria; that is, the consumers of library services in the city would probably be better off with fewer branches with the savings used either to lower taxes or increase other aspects of library services. Because the number of branches has grown since 1960 (and an additional branch is planned), one might conclude that efficiency has not been the operational criterion in the design of this library system. Library systems in other older cities may also be over branched, for example, in Chicago, Philadelphia, and San Francisco.

The analysis presented here could be improved in several ways. First, the estimates of use would be more accurate if attendance information were available for each location, even if only for sample periods. Second, the valuation of service might be improved with more detailed information about user travel time and costs in making Tibrary trips. 
HOW MANY HOURS AND BOOKS?

In the above exercise the hours of operation, books in stock, and books added during the year are not taken into consideration. Because these characteristics of public library service are also very important budget items, it is appropriate to try to determine whether they are provided at efficient levels. Of the three steps in an efficiency calculation, the main emphas is here will be on determining how use varies with differences in service--namely, the production function.

\section{Explaining Patterns of Use}

Three characteristics of library service are related to use: the size of the stock, the number of additions to it during the last year, and the number of hours the facility is open. The size of the stock of materials in the library indicates the variety of materials available. Presumably, the larger the stock, the more likely that a user will find material of particular interest. Information from the branch libraries of the New York Public Library allows disaggregation of stock into adult and juvenile categories and book and nonbook (mostly recordings) categories. However, paperback stock volumes are not recorded for each facility. Therefore, the book stock figures understate stock by the amount of paperbacks on hand. Further disaggregation might be useful (for example, fiction and nonfiction), but only if use information were similarly disaggregated.

The number of materials added during the most recent year indicates the currency of the material. Recently published materials, 
(for example, best sellers) are more in demand than older materials. Also, the library with a high volume of additions can respond to changes in users' tastes more quickly than the branch with a low volume of new materials, and should therefore be characterized by a higher rate of use. Additions are disaggregated in the same way as stock. No information about the addition of paperback books by branch is available.

Finally, the more hours the facility is open, the more accessible are the materials and the less planning a user must do in order to arrive when the library is open. The number of hours per week is calculated by dividing the total number of hours of service for the year by 52 .

In addition to the above three service characteristics, one might also consider the proportion of staff that is professional. A predominantly professional staff may be better able to respond to reference questions than a nonprofessional staff, and may also play a role in improving the selection and presentation of materials. Libraries also sponsor programs, such as story hours, films, book talks, and the like. If these are viewed as promotional activity for the library, more programs might generate more library use. However, the proportion of professional staff and the number of programs offered appear to be secondary to stock, additions, and hours as indications of library use, and preliminary statistical investigations confirm this supposition. Also, because only 59 neighborhood libraries are available for observation, the cross-branch 
statistical study has limited power to make fine distinctions in many dimensions. Therefore, these two secondary characteristics have not been taken into account in this analysis.

Library use can be disaggregated in several ways. The characteristics of service may influence different types of use differently. The most commonly observed indicator of use is circulation outside the library. Cross-system studies must control for differences in circulation caused by differences in the length of the loan period and in renewal policy; renewals typically are counted as additional circulations. By using branches within one system, such variation does not arise. Circulation statistics are disaggregated into adult and juvenile, book and nonbook categories, as is the stock information. The circulation figures, however, include the circulation of paperback materials, since library records do not distinguish between hard cover and paperback circulation. It is unfortunate that paperbacks are excluded from the stock figures but included in the circulation figures.

Circulation is only one component of library use; another is reference questions. The New York Public Library records the number of reference questions asked at each branch by adults and by juveniles during sample periods. Reference questions might be further disaggregated according to the skill and effort required to answer them. Such distinctions demand careful definitions and increase the cost of gathering the information. It is unusual for a library to keep detailed records 
of reference questions, and this study benefits by the quality of information from the New York Public.

The third major component of library use entails the use of materials and facilities in the library. For example, Newhouse and Alexander [13] found that a substantial number of visitors to the Beverly Hills Public Library did not use any library materials, but simply used the facility as a study hal1. Thus, an important category of library use is not reflected in data on circulation and reference questions. The simplest approach to monitoring in-library use would be to collect attendance information at each location. Sample surveys might provide more detailed data on rates of use of materials in the library. Because the New York Public Library does not maintain branch attendance records, we are unable to explore how service characteristics affect in-library use.

In all, 12 measures of use are related to service characteris tics: total circulation (book plus nonbook), book circulation, record circulation, and reference questions are each examined for adults, juveniles, and all users (adult plus juvenile). In terms of adult users, the stock and additions of adult materials are used as service characteristics; in regard to juvenile users, the stock and additions of juvenile materials are used. In examining the use of books, the stock and additions of books are used as service characteristics; for records, the stock and additions of records are used. Thus, each use is related to the most relevant feature of the service. In addition to the service characteristics specific to each branch, the location of each library relative to others may influence 
use. Forty-one of the 59 neighborhood branches are located with in one mile of another library facility. About one-sixth of neighborhood branch users indicated they live within 10 blocks of the library they use in a survey at 15 neighborhood branches. Library users do not seem to be clustered near the library. Therefore, it seems appropriate here to take explicit account of the spatial relationship amona branches. Hours of service is used as the most important service feature of competing branches. For each branch, the number of hours of service at every other branch is divided by the square of the distance between branches and summed. In the case of a branch located near other libraries offering many hours of service, the library interaction variable will be large. Where other libraries are distant and offer few hours of service, the library interaction variable will be sinall. A significant negative coefficient on the library interactior variable will indicate that the proximity of a competing branch tonds: to reduce library use at particular locations.

Library use is also determined by the lastes of peopla wiris live in the vicinity of the library. Berelsori, for example, cites several studies indicating that library use tends to increase with income and decline with age [2]. Feldstein emprasizes the findim that use increases with education [6]. Because income and education are closely related, it is difficult to distinguish the two effect: however, income is used here. Age distribution is measurer in terle: of the percent of total population enrolled in school belok: the college level.

In addition, access to libraries may be influenced by the: density of population in an area. Transit service, for exallifel mal: 
be better in a high-density area. People choosing to live in highdensity areas may have different tastes than individuals living in low-density areas, even controlling for income and age distribution. The use figures are not deflated by population, so one would expect greater use in higher density areas. Other neighborhood population factors which may influence library use include ethnicity, sex, occupation, and length of employment. However, these characteristics are thought to be secondary to population density, income, and schoo? enrollment, and preliminary statistical investigation confirms their secondary role. Because the neighborhood characteristic variables may reflect a constellation of neighborhood attributes, it is difficult to predict the signs of the coefficients of these variables; thus, two-tailed tests are applied.

Information about the three neighborhood attribute variables are available for 1970 by census tract. With over 700 tracts in the: three boroughs, there is no obvious way to match tracts to libraries; the New York Public Library has approached the jroblem by defining catchment areas for each branch using census tracts. Several catchment areas are defined for planned branches or for branches that have been scaled down to station status. Some catchment areas, comprised of several tracts, are quite large, while others are small. Moreover, the assignment of tracts to branches ultimately involves some arbitrary decisions. Obviously, the residents of one tract may use several different branches, depending on their location in the tract and their" preferences. Consequently, the catchment area notion is ignored here. 
Instead, the tract attributes are each weighted by the square of the distance to each branch and summed over all tracts. Fach borough is treated separately in this manier. By squaring distorite, the attributes of nearby tracts are heavily weighted, while the value of attributes of distant tracts drops rapidly toward zero. jistedicte cculd be raised to some power other than two-a study of individis! library users might yield a more precise paranteter value. bit strit an exercise is beyond the scope of the present study. Becalist the tract attributes are entered in the estimated reiatiorishifs as distance weighted indices, the absolute value of their ccefficients has no direct meaning.

The use relationship defined thus far purports to describe how users respond to library services. Bat the llanagers ot the Tibrary llay design the service in light of patterns of use. Thus, iit correlation between circulation and book stock niay reflect both tile fact that librery manajers provide large book stocks where use is krown to be ureat. Since the evaluation of efficiency reguires recolnting how user behavion responds to different services, it is ritcessery of distinguish user response functions frort the clivines liade by Tibrary mandiers. Therefore, stock, additions, hurs, and the schetia? inter

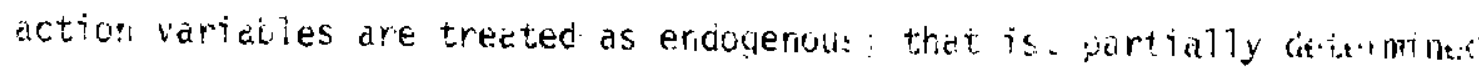

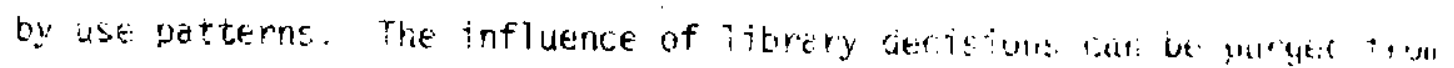
the bser response function by a two-stage estinkitun tertill?pue. The first stage cetermines estimated values for the endogenulu vartabli:t

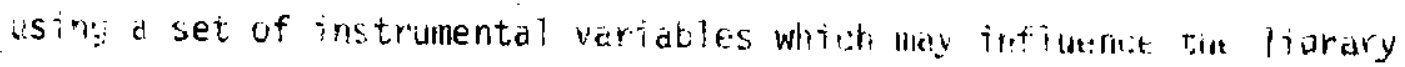
llanger's choices but which themseives do nit iritutice ust. 
Three groups of variables are used as instruments. Each reflects an influence on library decisions other than the desire to meet the demands of users. The first group is the cost of space. The cost of buying or leasing space for a library differs substantially within the city, and more branches can be efficiently provided in lowcost areas than in high-cost areas. Because no index of the cost of space for small areas in the city is readily available, land use information is used. The percent of land in residential use, and the percent of land in high-density areas with residential, industrial, and commercial use are entered as instruments relating to the cost of space [9]. The land use zone characteristics are weighted by the reciprocal of the squared distance to each library and summed. Nineteen-seventy census tract data on the value of housing units and contract rents is also used.

The second group of variables reflects the fact that library managers may be responsive to political pressures. The percent of votes for Mayor Beam in the 1973 election is used as an indicator of the political power of an area. This is, of course, a less-thanperfect measure of political power. The percent of registrants vating was used in preliminary investigations, but it proved no better than the Beam vote variable. Political power is a subtle, shifting attribute, and ethnic ties are often more important than geography. Although the mayor may be less important than other political figures, it nevertheless seems appropriate to include some measure of political activity, no matter how primitive. The Beam vote variable is recorded 
for a random sample of 987 electoral districts, weighted by the reciprocal of the square of the distance to each library, and summed.

The third group of factors influencing library decisions consists of lagged values of the variables. Branches are costly to move or expand, and book stock is likely to expand to fill the available space. Moreover, additions to stock and hours of service may tend to follow past patterns. Thus, inertia in the design of the library system is substantial; the current pattern of branches, stocks, and hours is not likely to be modified instantly to respond to each variation in use. Therefore the hours, stock, and additions in 1960 are included as predetermined variables and used as instruments in estimating use relationships. In the case of 11 neighborhood branches which were not open in 1960, zeros are entered. (Two of these branches were closed for renovation in 1960.)

The estimated use relationships are reported in Tables 4 through 7: Table 4 covers total circulation (book and nonbook), Table 5 covers book circulation, Table 6 record circulation, and Table 7 reference questions. Each relationship is estimated for the 59 neighborhood libraries. The regional branches and centers are excluded because they may offer a wider assortment of services not reflected in the service attributes measured. (In fact, results with regional libraries or with centers do differ somewhat from those for neighborhood branches alone.) An ordinary least squares (OLS) estimate and a two-stage least squares (TSLS) estimate are reported for each relationship. One-tailed tests are applied to the four library attributes: positive coefficients are expected for stock, additions, and hours, while a 


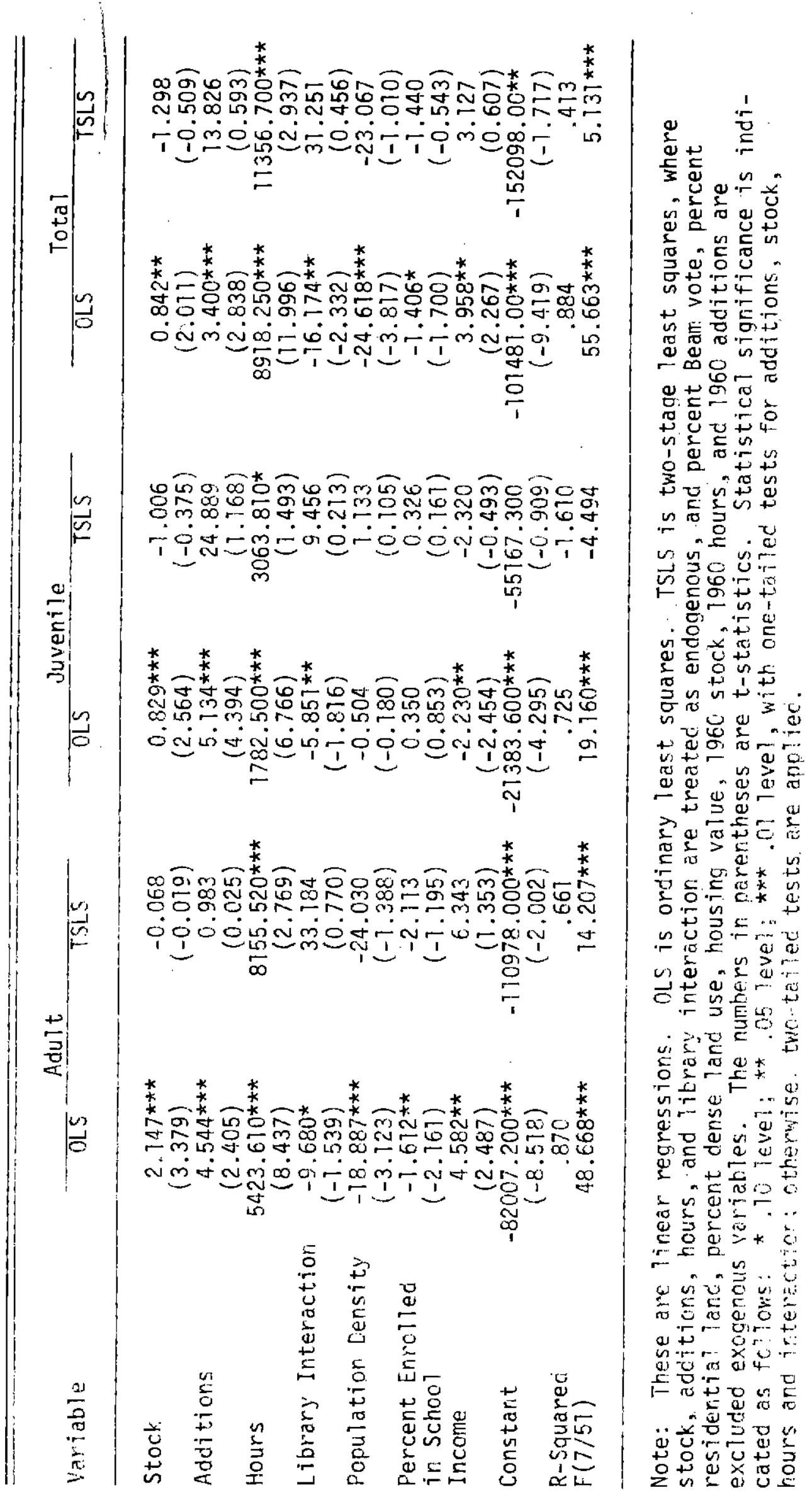




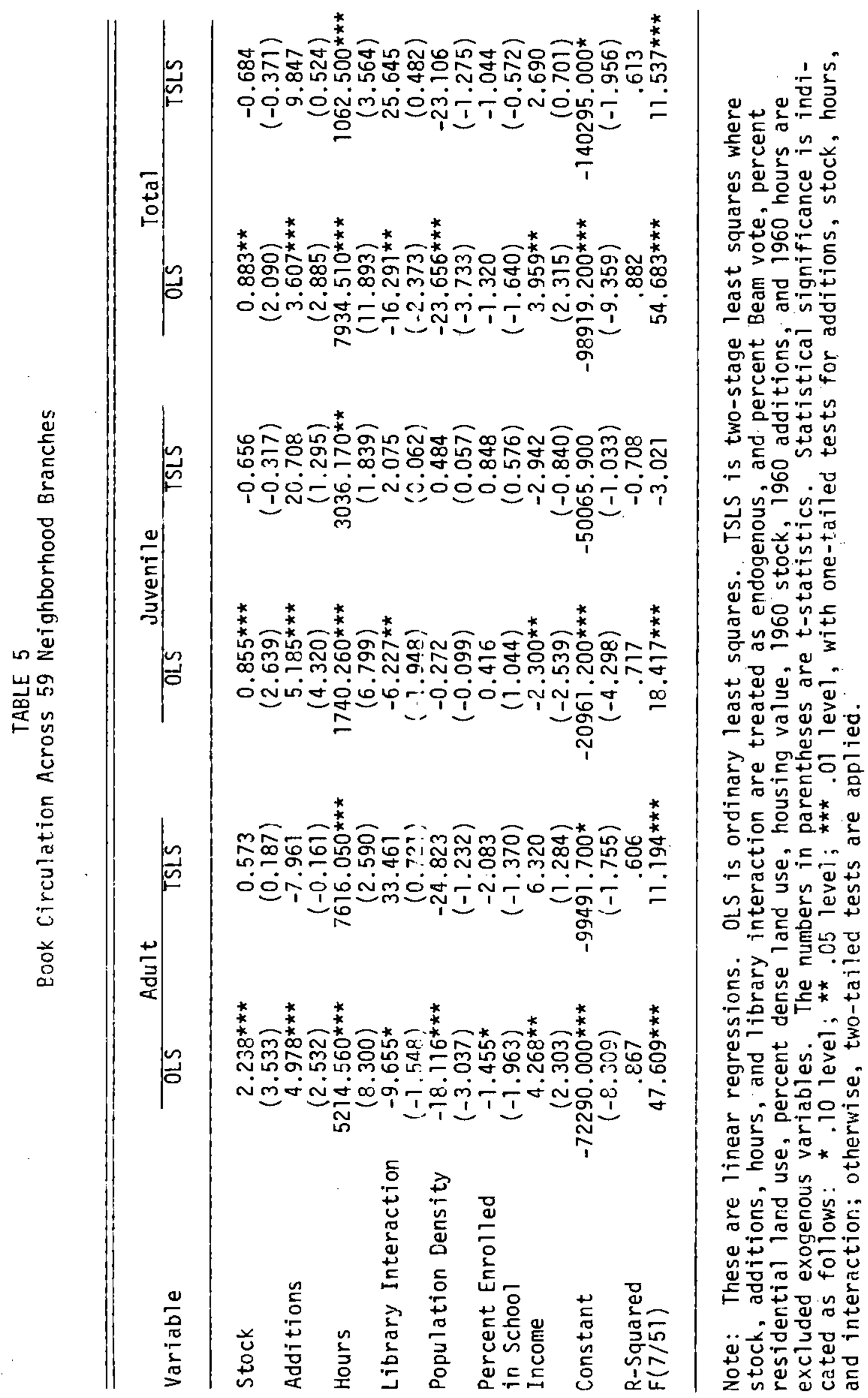




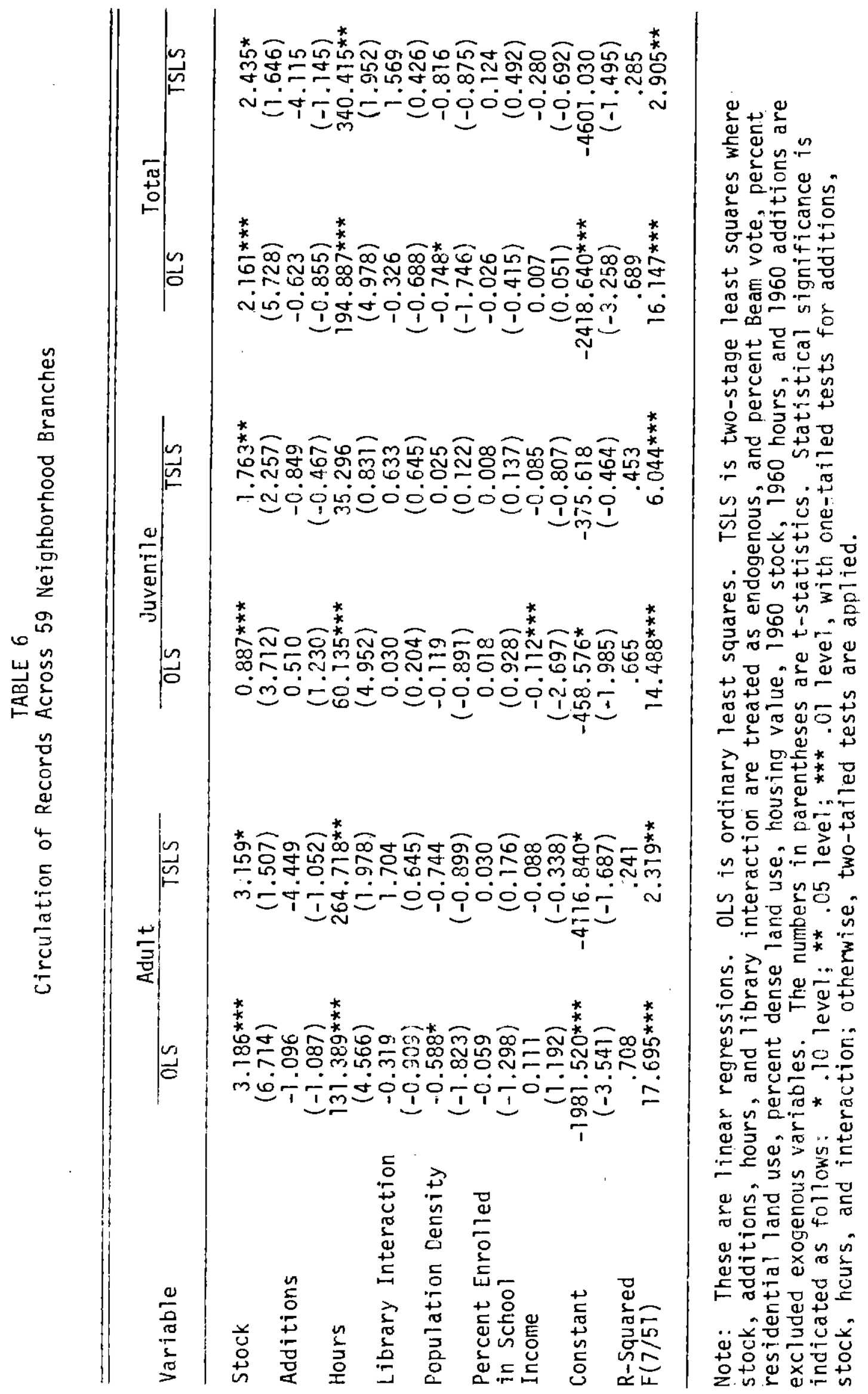




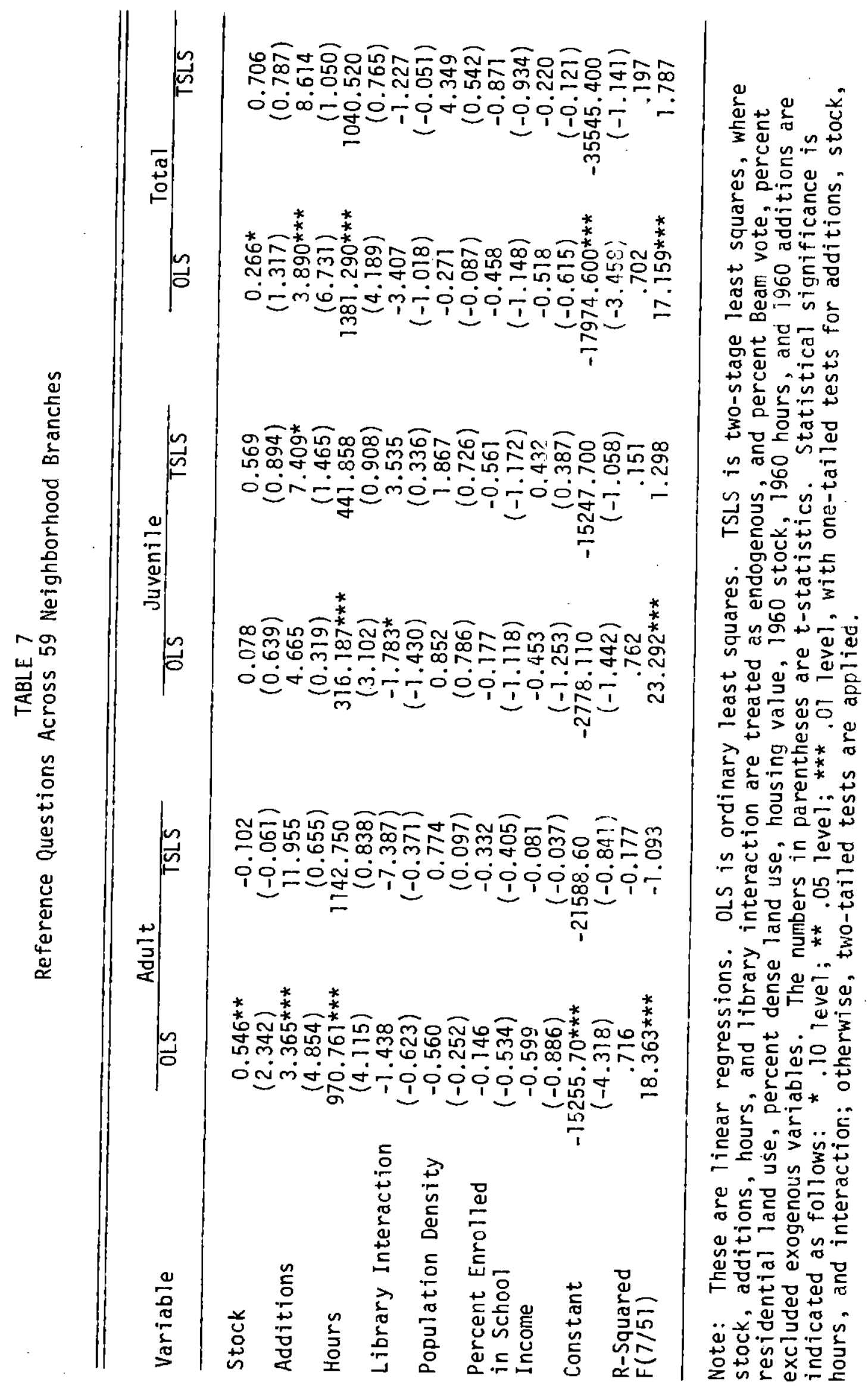


negative coefficient is expected for library interaction. Two-tailed tests are applied to the other coefficients.

The most dramatic result is the relationship between use and hours of service; the amount of use of a library is very significantly associated with the number of hours of service. Currently, the neighborhood branches average just under 20 hours per week of service, down from 39 hours in 1960. The association between use and hours holds for both adult and juvenile materials, for books and records, and for reference questions.

Moreover, the result for hours persists in the two-stage estimates, where, for the most part, the influence of the other service attributes does not remain statistically significant. If the two-stage estimates are interpreted as the more correct estimates of user response, with the influence of library decisions purged by the first stage, then consumers seem much more responsive to changes in hours than to other attributes of service.

Stocks and additions also have statistically significant coefficients. Additions seem to be more important in relation to book circulation, while the quantity in stock is a more important variable in record use. Thus, it seems that books become obsolete faster than records. Perhaps best sellers are more important to public library patrons than are the largest selling records. The number of additions also appears to be important for reference questions, since currency of materials is associated with use.

Stock and additions do not appear to be significantly associated with use in the two-stage estimates, except for record circulation. In terms of book circulation and adult reference questions, the stock 
of materials and additions to stock do not appear to be significant factors in use decisions. This lack of significance may be due to the weakness of the instruments in explaining library decisions; twostage estimates are not as reliable as ordinary least squares.

The library interaction variable has a statistically significant negative coefficient in the total circulation and book circulation and in the juvenile reference question ordinary least squares estimates. The statistical significance of these coefficients reinforces the finding that the existence of nearby branches tends to reduce the use of a neighborhood library.

The three neighborhood characteristic variables yield some surprising results. First, population density shows a statistically significant negative relationship with book and record use by adults and no significant positive coefficient. Thus, the notion that library use will be greater in higher density areas because of easier access does not seem to hold. Rather, the tastes of people living in high- and low-density areas differ: those living in low-density areas appear to have a stronger preference for library services than those living in high-density areas, with income held constant.

Income has the expected positive coefficient for adult book use, but a surprising negative coefficient for juvenile book use. Since juvenile books are relatively inexpensive, perhaps higher-income households buy more juvenile books than low-income households and rely on the library to obtain the more expensive adult books.

The percent of population enrolled in school has an unexpected negative coefficient for adult book use and no other significart 
coefficients. Because school enrollment is closely related to the number of young persons living in an area, and because library use is generally thought to decline with age, a positive sign would be expected. The negative coefficient indicates that adult book use is greater where there are fewer children.

The overall statistical power of the relationships is significant in all cases except the two-stage results for juvenile book use and for reference questions. The library service characteristics are strongly associated with library use in expected ways. The neighborhood characteristics also help explain library use, but in somewhat surprising ways. The two-stage results, while generally weaker than the ordinary least squares, emphasize the importance of hours of service as a determinant of patterns of use.

\section{Efficient Operations}

Using these careful estimates of relationships between 1 ibrary service characteristics and use, it is now possible to determine service efficiency in terms of hours, stock, and additions. The marginal costs of each activity were reported in Table 2 . The marginal benefits of an additional unit of each activity are calculated in Table 8 . The coefficients of the regressions in Table 4 and 7 are estimates of how use will respond to an increment in a particular library activity, other things equal. By weighting circulation by 1.183 to account for in-library use and adding reference questions one arrives at an estimate of the total increase in library use associated with one more unit of activity. Marginal use figures are reported in column (b) of Table 8 . Thus an additional hour of service is associated 


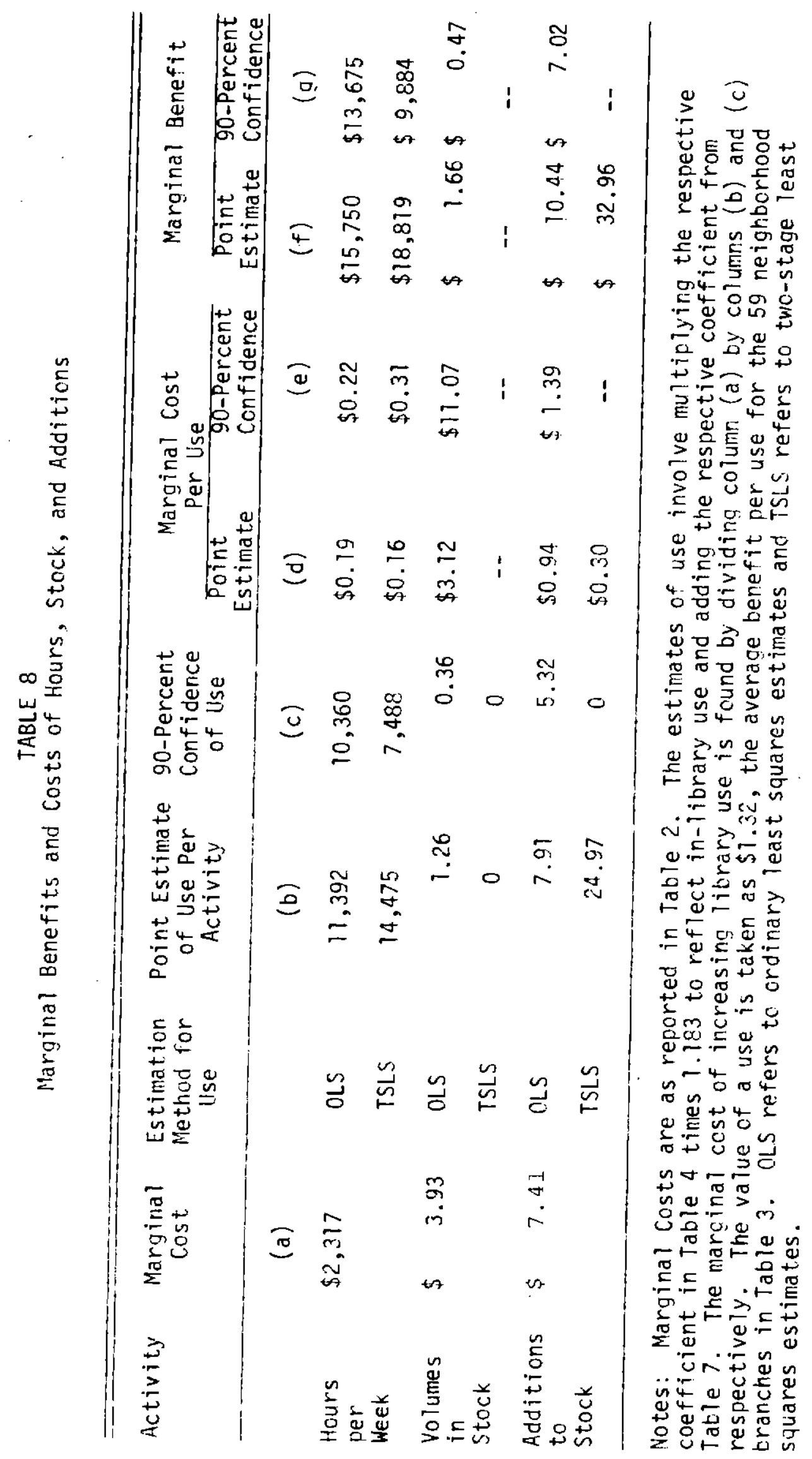


with 11,392 more uses of the library using the ordinary least squares results, 14,475 using the two-stage results. Because the coefficients are subject to statistical error, it is appropriate to report a 90 percent confidence interval for the associated difference in use. The 90 percent confidence intervals are reported in column (c).

By dividing the marginal cost of an activity, say an additional hour of service, by the expected increase in use resulting, one can estimate the marginal cost of increasing library use in different ways, as reported in columns (d) and (e) of Table 8 . The ordinary least squares estimates indicate that an additional library use could be: generated for each $\$ .19$ spent in expanding hours. Spending $\$ 3.12$ in expanding the size of the book stock at a branch will be expected to increase library use by 1 . Spending an additional $\$ .94$ for new materials would expand library use by one.

An efficiently designed library system would expand each activity as long as the marginal benefit of an extra unit of the activity--for example, an extra hour of service--exceeds the cost of providing the extra urit. If the cost of an extra unit of the activity exceeds the benefit derived, then consumers would be better off with the savings in tax dollars or expenditure on a more productive item, and that activity should be cut back. As an activity is expanded, we expect that less benefit will be derived from each additional unit. As an activity is reduced, we expect each additional unit of cutback to have a larger impact on benefits. Thus, the estimates of marginal benefits presented here reflect the marginal values of current levels of library activities. The marginal benefits will differ at different levels of activity. 
The average benefit of a library use at the 59 neighborhood libraries presented in Table 3 is $\$ 1.32$, although there is substantial variation among the branches. The marginal benefit of an additional unit of activity can be compared with the marginal cost of the activity either by comparing the marginal cost per use of columns (d) and (e) with the value of benefits, $\$ 1.32$, or by multiplying the estimated changes in use, columns (b) and (c) and comparing with marginal cost of the activity, column (a).

The marginal benefit of an additional hour of service each week substantially exceeds the assumed marginal cost. Using either the ordinary least squares or two-stage estimates, the point estimates or the 90 percent confidence intervals, the marginal gains fronl additional hours substantially exceed the marginal cost. The average of 20 hours per week offered at the 59 neighborhood branches of the New York Fublic Library is too low for efficiency. Expanded hours of service would generate substantial increase in library use wor th more to consumers than the costs of the expanded service.

The marginal benefits of maintaining more volumes in stock is less than the marginal benefits derived. Thus, on average the neighborhood branches of the New York Public Library seem to be too large for efficiency. Because the biggest impact of stock on use seems to be for recordings, it may be that maintainina a larger stock of recordings is justified.

The acquisition of new materials seems to have benefits that exceed costs, at least for the point estimates. Thus, while the evidence is not as clear as for hours, there does seem to be a case 
for acquiring more new materials. New materials seem to generate use worth more than their cost.

\section{FEWER BRANCHES OPERATING MORE HOURS}

Overall, then, there seems to be too many branches operating too few hours, buying somewhat too few new materials, but maintaining a stock of materials that may be somewhat too large. The evidence for the number of branches and the number of hours of service is quite clear, the evidence on stocks and new materials is less clear. Because the current mix of library activities favors extra branches rather than more hours of service, it is not possible to say whether the current. budget is at the right level or not. The important finding is that an efficient library design would have fewer branches and operate more hours per week.

The influence of a hypothetical reallocation of budget to fewer branches operating ionger hours can be estimated using the information developed above. The first step is closing branches. For the sake of the exercise, suppose that the seven branches with benefits at least $\$ 175,000$ less than costs were closed. None of the seven are next to each other. 5 The ciosings would lead to an annual cost savings of $\$ 1.9$ million dollars including the rental value of the space. With the branches closed, some of the library use would shift to remaining branches. For the sake of this exercise, let's assume that all the use shifts to nearby branches. In addition, some of the branches that are closed may have been nearest to some remaining branches. The best alternative for these remaining branches will now 
be a more distant branch. Consequently, the value of library services at the next nearest branches will be greater.

The second step of this exercise is to assume that the cost saving from closing the seven branches is used to increase the hours of service at the remaining 69 facilities in the system. At $\$ 2,317$ per hour, the $\$ 1.9$ million made available by closing the seven branches will buy 11.9 hours each week for each remaining facility in the system. If each hour added 14,475 uses as suggested by the two-stage point estimates, the use of each branch would be expected to increase by more than 172,000 .

The costs and benefits of each branch if 7 neighborhood branches were closed and the funds reallocated to longer hours are reported in Table 9. Of the remaining 53 neighborhood branches, only. 4 have negative net benefits following the branch closings and expansion of hours. The assumption that the hours would be expanded the same at every facility is perhaps overly simple. The assumption that each additional hour will have the same impact in increasing use as the estimate of the first hour may be too strong. Nevertheless, the change in the efficiency of the operation--in the quality of service given the budget--is striking. Of course, the changes will make people in areas where branches are closed travel farther to get library services, and so they can be expected to oppose the shift. On the other hard, perhaps a branch system with fewer branches should have locaticns different than the current locations. The relocation of branches is not examined here. 
TABLE 9

Estimated Use, Benefits and Cost of System with 7 Branches Closed

\begin{tabular}{|c|c|c|c|c|}
\hline $\begin{array}{l}\text { Neighborhood } \\
\text { Libraries }\end{array}$ & Use & Benefit & $\cos t$ & Benefit-Cost \\
\hline Allerton & 321,227 & 372,379 & 311,753 & 60,626 \\
\hline Baychester & 492,407 & 683,185 & 389,513 & 293,672 \\
\hline Castle Hill & 221,154 & 257,774 & 197,121 & 60,653 \\
\hline City Island & 207,879 & 551,963 & 106,701 & 445,262 \\
\hline Clason's Point & 277,993 & 350,453 & 280,337 & 70,116 \\
\hline Eastchester & 246,753 & 295,431 & 154,853 & 140,578 \\
\hline Edenwald & 284,030 & 464,650 & 224,427 & 240,223 \\
\hline High Bridge & 251,005 & 268,700 & 226,765 & 41,935 \\
\hline Jerome Park & 405,962 & 408,848 & 209,451 & 199,397 \\
\hline Kings bridge & 326,798 & 312,547 & 313,576 & $-1,028$ \\
\hline Melrose & 304,976 & 403,803 & 227,440 & 176,363 \\
\hline Morrisania & 236,726 & 313,436 & 259,364 & 54,072 \\
\hline Mosholu & 356,730 & 473,232 & 259,013 & 214,219 \\
\hline Mott Haven & & 0 & 0 & 0 \\
\hline Parkchester & 376,041 & 414,547 & 243,347 & 171,200 \\
\hline Pelham Bay & 361,622 & 524,785 & 248,183 & 276,602 \\
\hline Riverdale & 296,389 & 475,851 & 271,011 & 204,840 \\
\hline Sedgwick & 358,730 & 349,833 & 113,735 & 236,098 \\
\hline Soundview & 274,369 & 322,232 & 240,623 & 81,609 \\
\hline Spuytenduyvil & 334,465 & 319,882 & 245,295 & 74,587 \\
\hline Throgs Neck & 283,762 & 520,333 & 241,983 & 278,350 \\
\hline Tremont & 359,106 & 384,387 & 201,660 & 182,727 \\
\hline Van Cortlandt & 252,731 & 308,355 & 146,820 & 161,536 \\
\hline Van Nest & 318,256 & 381,846 & 233,933 & 147,913 \\
\hline Wakefield & 266,758 & 325,471 & 292,506 & 32,965 \\
\hline West Farms & 0 & 0 & 0 & 0 \\
\hline Woodlawn Height & 231,009 & 281,853 & 131,723 & 150,130 \\
\hline Woods tock & 0 & 0 & 0 & 0 \\
\hline Aguilar & 246,461 & 266,178 & 252,767 & 13,411 \\
\hline Cathedral & 259,956 & 201,476 & 140,487 & 60,989 \\
\hline Chatham Sq. & 474,589 & 593,236 & 303,036 & 290,200 \\
\hline Columbia & 265,355 & 249,434 & 108,155 & 141,279 \\
\hline Columbus & 214,144 & 256,972 & 191,519 & 65,454 \\
\hline Epiphany & 435,460 & 367,528 & 310,021 & 57,507 \\
\hline 58 th Street & 373,027 & 298,421 & 238,717 & 59,704 \\
\hline George Bruce & 0 & 0 & 0 & 0 \\
\hline Ham Fish Park & 281,909 & 253,718 & 227,959 & 25,759 \\
\hline Hamilton Grange & 293,326 & 293,326 & 270,780 & 22,546 \\
\hline Harlen & 208,772 & 198,333 & 178,875 & 19,458 \\
\hline Hudson Park & 232,175 & 196,885 & 222,088 & $-25,203$ \\
\hline Kips Bay & 347,506 & 284,955 & 256,907 & 28,048 \\
\hline Ma combs Bridge & 190,528 & 190,528 & 63,116 & 127,412 \\
\hline Muhlenberg & 291,211 & 306,354 & 232,168 & 74,186 \\
\hline 115 th Street & 198,850 & 182,942 & 197,987 & $-15,045$ \\
\hline 125th Street & 0 & 0 & 0 & 0 \\
\hline
\end{tabular}


TABLE 9--continued

\begin{tabular}{|c|c|c|c|c|}
\hline $\begin{array}{l}\text { Neighborhood } \\
\text { Libraries }\end{array}$ & Use & Benefit & $\cos t$ & Benefit-Cost \\
\hline 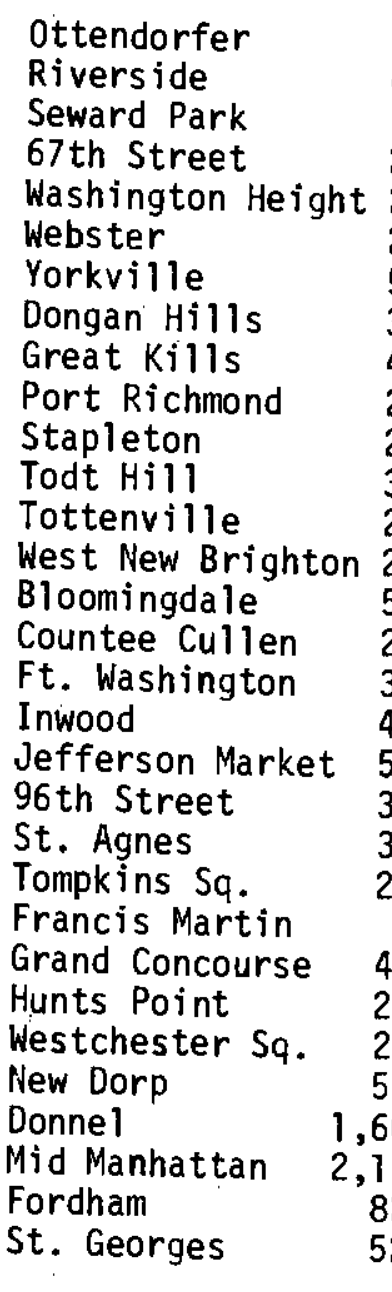 & $\begin{array}{r}263,021 \\
494,054 \\
0 \\
274,065 \\
231,433 \\
240,250 \\
506,607 \\
314,335 \\
402,298 \\
299,735 \\
236,978 \\
325,028 \\
219,469 \\
296,376 \\
514,954 \\
259,929 \\
314,213 \\
405,400 \\
540,170 \\
304,662 \\
325,784 \\
242,203 \\
0 \\
435,715 \\
290,922 \\
264,114 \\
522,749 \\
, 603,256 \\
2,110,901 \\
820,093 \\
526,373\end{array}$ & $\begin{array}{r}216,940 \\
469,351 \\
0 \\
263,102 \\
203,661 \\
206,615 \\
435,682 \\
706,109 \\
1,372,093 \\
481,381 \\
394,388 \\
741,480 \\
1,610,902 \\
475,980 \\
1,287,384 \\
987,730 \\
1,791,012 \\
2,716,178 \\
972,305 \\
685,611 \\
586,411 \\
460,185 \\
0 \\
797,881 \\
910,702 \\
810,090 \\
3,456,419 \\
1,563,495 \\
(a) \\
6,314,715 \\
4,173,509\end{array}$ & $\begin{array}{r}204,491 \\
289,891 \\
0 \\
239,185 \\
232,298 \\
154,654 \\
341,638 \\
214,581 \\
241,586 \\
220,014 \\
154,323 \\
179,925 \\
117,082 \\
173,730 \\
436,246 \\
438,974 \\
353,080 \\
363,633 \\
543,374 \\
313,760 \\
329,911 \\
260,658 \\
0 \\
354,121 \\
312,920 \\
307,623 \\
345,825 \\
2,387,566 \\
(a) \\
706,429 \\
506,487\end{array}$ & $\begin{array}{r}12,449 \\
179,460 \\
0 \\
23,917 \\
-28,637 \\
51,961 \\
94,044 \\
491,528 \\
1,130,507 \\
261,367 \\
240,065 \\
561,555 \\
1,493,820 \\
302,250 \\
851,138 \\
548,756 \\
1,437,932 \\
2,352,545 \\
428,931 \\
371,851 \\
256,500 \\
199,527 \\
0 \\
443,760 \\
497,782 \\
502,467 \\
3,110,594 \\
-824,071 \\
(a) \\
5,608,286 \\
3,667,022\end{array}$ \\
\hline
\end{tabular}

Note: Closing 7 facilities allows $\$ 1.9$ million in expenditure to be distributed over the remaining 69 facilities, adding 11.9 hol rs of service at each attracting 172,014 addition uses. The use of the closed branches are reassigned to nearby branches, and the distances to the nearest branch is changed with the closings.

(a) not applicable. 


\section{A POLICY PERSPECTIVE}

The above findings may be difficult to convert into policy. The political process shapes library expenditure patterns, and efficiency considerations may not dominate the political scene. First, the political process recognizes the history of the institution and the possibility of seemingly irreversible changes. Second, equity consideration may play some role. Third, federal policy may have some impact on local choices. Fourth, the political process may be simply imperfect.

The current operation of the New York Public Library reflects the severe budget cutbacks of the 1970's. Instead of cutting back both hours and branches in an effort to retain an efficient mix, the Library has cut back hours severely while retaining almost al1. branches. Cutting back hours has been politically easier than closing branches. In January, 1976 the Library announced the planned closing of 8 branches as a way of coping with budget cuts. The announcement of closings created a substantial political reaction that prevented closings. Neighborhood citizen groups coalesced around the preservation of individual branches. While reductions in hours might be seen as temporary, the closing of branches may have been seen as permanent. Rather than accept the budget cuts as permanent, the political friends of the Library may have viewed cutting hours as a way of preserving the option of restoring former service levels.

On the other hand, the Library had been expanding the Library system into the 1970's. In 1960, 48 of the present 59 neighborhood 
branches were operating and two others were closed for renovation. Thus, the number of neighborhood branches has grown by more than 15 percent over the last 20 years. Of the nine new neighborhood branches, six have opened since 1970. While the opening of new branches may have been an appropriate response to the changing location of library use, it may be that older branches should have been closed at the same time.

In 1960 neighborhood branches were open an average of 39 hours each week. Other urban library systems currently average in excess of 40 hours per week at branch locations. In 1970, however, the neighborhood libraries in New York averaged 48 hours of service per week, an above average number. The substantial growth in branch library activity during the 1960's, even as library use began to decline (it peaked in 1964), did not put the Library in a very good position to deal with the budget cutis in the 1970's.

Equity considerations may also play a role in shaping politicāl support for the Library. Public library services are sometines discussed in terms of their value for poor people. At the turn of the century and again during the Great Depression, the public library provided recreation without charge and offered access to learning for adults eager to better themselves. Evidence of the distributional consequences of library activities is not overwhelming, however.

If the net effect of the local government's library' expenditures is to improve the relative position of poor people, then the beneficiaries of the services must have lower incomes on average than people who bear the burden of the taxes used to pay for the services. 
The question of the incidence of the taxes used to pay for the library is not simple. Currentiy, over a quarter of the employees of the branch libraries of the New York Public Library are paid with federal Comprehensive Employment and Training Act (CETA) funds. Presumably, general revenue-sharing funds also have an impact. Federal revenue sources are moderately progressive. The share of library revenues accounted for by local tax sources may be less than 50 percent. The most important local tax is the property tax. Recent literature on the property tax indicates that it may be capitalized into land values or borne by the owners of capital. Therefore, the property tax is likely, except for administrative deviation, to be somewhat progressive. Those individuals earning higher incomes pay relatively more in taxes supporting local services than those earning lower incomes.

The beneficiaries of the service also seem to be disproportionately higher income earners. In particular, we find that adult use of the library is greater in areas with higher-income residents, whereas the use of juvenile materials seems greater in lower-income areas. Use as reflected by reference questions appears to be unrelated to income. Because the use of juvenile materials accounts for less than 30 percent of total use, the aggregate effect seems to be that higher income households use the library more than lower income households. This finding is generally in conformance with those of other studies, although the others do not differentiate between adult and juvenile use. Because the income variable is a distance-weighted index of census tract information, the coefficients cannot be used to calculate income elasticities of use. 
If both the sources of finance and the use of the library are disproportionately represented among higher-income groups, it is possible that local expenditure on public library services is distributionally neutral. However, since neither the distribution of those who finance libraries nor the distribution of those who benefit from library services is very carefully observed, no firm conclusion about distributional consequences can be made.

Note, however, that just because the beneficiaries tend to have higher incomes or the services are distributionally neutral, this does not mean that the services should not be performed in the public sector. Even though not all citizens use the library, it may still have characteristics that make it substantially public in character, justifying its support by general taxes. That library users gain by library expenditure relative to nonusers does not in itself prove an inequity in the fiscal system. Nonusers may value the option of using the library, and so the apparent inequity may overstate the underlying welfare effect. Moreover, the important equity result is the net effect of the full fiscal system. Nonusers may gain disproportionately from other government services. The important equity result is that for the full fiscal system; there is no reason why each service matched with its source of finance should be distributionally neutral or progressive. Finally, the net benefit of services may be capitalized into land values.

Since in-library use has not been observed, we do not know the distributional gains from such use. Is in-library use greater 
among lower-income groups? A better understanding of the distributional consequences of library activity requires more information on in-library use, particularly attendance data by branch.

Suppose that we accept the view that library services are distributionally advantageous. Suppose, too, that library services are used effectively by poor people, especially children, and that library use improves school performance and literacy levels, and is an important vehicle for social advancement by low-income urban families. (Note that each of these claims is unproven and indeed difficult to prove; the important issue is the effectiveness of libraries relative to other expenditures.) How would public library services best be provided to low-income households? The very substantial response of use of all kinds to the number of hours of service suggests that even low-income households respond to the number of hours. The high density of branches in low-income areas of the city, on the other hand, does not appear to have generated very high levels of use. It seems likely that the results of this study may also apply to library use by lowincome persons; that is, low-income library users, like the average user, might be better served by longer hours in fewer larger branches. Low-income families may also value their time at lower rates than highincome families. Thus, it is not obvious why library services should be characterized by more branches and fewer hours of service in consideration of equity.

The combination of more branches and fewer hours of service may also be explained by the political environment that shapes the library system. Perhaps public library service is quite local relative 
to the size of the city. The benefits of service in a particular location may be concentrated in a small area, while the costs of providing the branch service are widely diffused. Neighborhood demands for services may be made with little concern for costs; in effect, there may be a frue rider among neighborhoods, with weak central control. This hypothes is represents a substantial simplification of a complex historical process which deserves more careful study. The point is that distributional impact across neighborhoods may play some political role.

Federal policy may have some impact on Library decisions. As already noted, over 25 percent of Library employees are federally financed CETA workers. President Carter has proposed new restrictions on CETA funds that would prevent professional librarians being employed with CETA funds. The central fact is that a substantial part of Library operations are contingent on the availability of federal CETA funds. In the present setting funding cuts lead to cuts in hours.

Federal grants are also supporting the construction of a new branch. While public works projects may be an appropriate response to high levels of unemployment in the city, the further expansion of library branches in a system already overburdened with too many branches is of questionable value. The operating costs of the new facility may force the further cutback in hours in other facilities. Six new branches in the Queens Borough Public Library, a separate system, remain unopened for lack of operating funds. 
Finally, one must question whether the political constraints on the Library that have prevented a more rational response to budget cuts are perfectable. Presumably library users who live near branches that would be closed would be made worse off by the closing. At least those who have flexible enough schedules to be able to use the facility when it happens to be open may be worse off. Are such the dominant force in shaping the library services? $O r$ is the tactic of preserving locations at the cost of low levels of operation throughout the system one that will yield more funds for libraries over some longer term? Perhaps better information about Library operations will improve the political outcome.

\section{FURTHER RESEARCH}

This essay may set the stage for additional efforts to understand efficiency in public libraries. The library use relationships might be estimated with different functional forms. They might also be explored overtime in an effort to discover why use began to fall perhaps a decade before services were cut. The lack of annual demographic information may hamper this inquiry. Finally, a study of individual users might refine the estimated relationships presented here. 
NOTES

IAn earlier version of this essay appeared as Working Paper \#55 of the Joint Center for Urban Studies of the Massachusetts Institute of Technology and Harvard University. Comments received at the Joint Center, at Yale, and at Vanderbilt have been helpful in making revisions. I would like to thank Richard Couper, John Cory, and Edwin Holmgren of the New York Public Library for their help with this study.

2 A recruit professional librarian has an annual salary of about $\$ 11,220$ and works a 35 hour week. Fringe benefits are about 30 percent of base salary. These figures imply a recruit librarian costs about $\$ 8$ per hour. $\$ 44.56$ per hour of library service suggests that the observed marginal costs of additional hours of public service are well above the extra cost of an additional librarian for a single hour.

${ }^{3}$ The relationship between stock and cost can be explored by relating costs to square feet and square feet to stock. The number of square feet in a facility are regressed on the stock of materials:

Square Feet $=6633.29+0.029$ juvenile stock +0.024 adult stock

$$
\begin{array}{lll}
(3.647) & (0.187) & (0.233) \\
+ & 2.200 \text { record stock } & \text { R-squared }=0.07 n=59
\end{array}
$$

Among the neighborhood branches, there seems to be little relationship between the stock and space. For the whole system, the relationship is stronger. The number of square feet in the facility are related to maintenance and security costs: 


$$
\begin{aligned}
& \text { Maintenance Cost }=5249.0+\$ 1.29 \text { square feet } R \text {-squared }=0.70 \\
& (4.554)(11.80) \quad n=59
\end{aligned}
$$

The marginal maintenance cost of $\$ 1.29$ per square foot plus the approximate annual lease value of $\$ 5$ per square foot suggests an annual space charge of $\$ 6.29$ per square foot. Because the link between stock and space seems so weak among neighborhood branches it is not possible to relate the estimated space costs to the stock cost.

4The average cost for an adult hardback book including library discounts was $\$ 7.09$; for a juvenile hardback the average price was $\$ 4.16$. The average price for an adu1t paperback was $\$ 1.98$ and for a juvenile paperback $\$ 1.26$. About 28 percent of library acquisitions are paperback. Processing including ordering and cataloging adds an average of 34 percent to the cost of the materials. The processing costs on paperbacks are much lower than for hardbacks. These figures confirm the estimate of $\$ 7.31$ for the average new addition to stock.

5The seven marginal branches are: Mott Haven, West Farms, Woodstock. and Francis $X$. Martin Regional in the Bronx, and 125th Street, Seward Park, and George Bruce in Manhattan. 


\section{REFERENCES}

1. W. J. Baumol and M. Marcus, "Economics of Academic Libraries," American Council on Education, Washington, D.C., 1973.

2. B. Berelson, "The Library's Public," Columbia University Press, New York, 1949.

3. S. W. Black, Library Economics, in "Libraries at Large" (D. M. Knight and E. S. Nourse, eds.), Bowker, New York, 1969.

4. R. Crowley and T. Childers, "Information Services in Public Libraries: Two Studies," Scarecrow Press, Metuchen, N.J., 1971.

5. E. R. DeProspo, E. Altman and K. E. Beasley, "Performance Measures for Public Libraries," Public Library Association, Chicago, 1973.

6. K. F. Feldstein, "The Economics of Public Libraries," Ph.D. dissertation, M.I.T., 1977.

7. H. C. Goddard, "A Study in the Theory and Measurement of Benefits and Costs of the Public Library," Ph.D. dissertation, Indiana University, 1970.

8. M. Hamburg, R. C. Clelland, M. R. W. Bommer, L. Ramist, and R. M. Whitfield, "Library Planning and Decision Making Systems," M.I.T. Press, Cambridge, Mass., 1974.

9. Hazen and Sawyer for the Department of City Planning and the Department of Water Pl inning, "Revised Nine Month Report: Area Waste Treatment Management Planning," City of New York, 1978.

10. T. Hu, B. H. Booms, and L. W. Kaltreider, "A Benefit-Cost Analysis of Alternative Library Delivery Systems," Greenwood Press, Westport, Ct., 1975. 
11. F. W. Lancaster, "The Measurement and Evaluation of Library Services," Information Resources Press, Washington, D.C., 1977.

12. P. M. Morse, "Library Effectiveness: A Systems Approach," M. I.T. Press, Cambridge, Mass., , 1968.

13. J. P. Newhouse and A. J. Alexander, "An Economic Analysis of Public Library Services," Heath, Lexington, Mass., 1972.

14. Public Library Association, Standards Committee, "Minimum Standards for Public Library Systems, 1966," American Library Association, Chicago, 1966.

15. J. A. Raffel and R. Shishko, "Systematic Analysis of University Libraries: An Application of Cost-Benefit Analysis to the M.I.T. Libraries," M.I.T. Press, Cambridge, Mass., 1969.

16. C. A. Seymour and J. L. Schofield, "Measuring Reader Failure at the Catalogue," Library Resources and Technical Services 17, $6-24,1973$.

17. P. J. Stratton, "Public Libraries: Their Structure, Use and Cost of Service Provision," Ph.D. dissertation, Northern Illinois University, 1977. 